\title{
Corrigendum: Exercise: A Protective Measure or an "Open Window" for COVID-19? A Mini Review
}

\author{
João B. Ferreira-Júnior ${ }^{1 *}$, Eduardo D. S. Freitas ${ }^{2}$ and Suene F. N. Chaves ${ }^{3}$ \\ ${ }^{1}$ Federal Institute of Sudeste of Minas Gerais, Campus Rio Pomba, Rio Pomba, Brazil, ${ }^{2}$ Neuromuscular Laboratory, \\ Department of Health and Exercise Science, University of Oklahoma, Norman, OK, United States, ${ }^{3}$ Department of Sports, \\ Federal University of Minas Gerais, Belo Horizonte, Brazil
}

Keywords: coronavirus, immune system, endurance training, resistance training, blood flow restriction, no load resistance training

\section{A Corrigendum on}

Exercise: A Protective Measure or an “Open Window” for COVID-19? A Mini Review by Ferreira-Júnior, J. B., Freitas, E. D. S., and Chaves, S. F. N. (2020). Front. Sports Act. Living 2:61. doi: 10.3389/fspor.2020.00061

In the original article, the reference for Chen et al. (2020) was incorrectly written as Chen, P., Mao, L., Nassis, G. P., Harmer, P., Ainsworth, B. E., and Li, F. (2020). Wuhan coronavirus (2019-nCoV): the need to maintain regular physical activity while taking precautions. J. Sport Heal. Sci. 9, 103-104. doi: 10.1016/j.jshs.2020.02.001. It should be Chen, P., Mao, L., Nassis, G. P., Harmer, P., Ainsworth, B. E., and Li, F. (2020). Coronavirus disease (COVID-19): The need to maintain regular physical activity while taking precautions. J. Sport Health. Sci. 9, 103-104.

\section{OPEN ACCESS}

Edited and reviewed by: Jun Sugawara,

National Institute of Advanced Industrial Science and Technology (A/ST), Japan

${ }^{*}$ Correspondence: João B. Ferreira-Júnior jbfjunior@gmail.com

Specialty section:

This article was submitted to

Exercise Physiology,

a section of the journal

Frontiers in Sports and Active Living

Received: 10 June 2020

Accepted: 30 June 2020

Published: 14 August 2020

Citation:

Ferreira-Júnior JB, Freitas EDS and Chaves SFN (2020) Corrigendum: Exercise: A Protective Measure or an "Open Window" for COVID-19? A Mini

Review.

Front. Sports Act. Living 2:101. doi: 10.3389/fspor.2020.00101 doi: 10.1016/j.jshs.2020.02.001.

In the original article (Flynn et al., 1999) was not cited or it was replaced by Fahlman et al. (2000). The citation has now been inserted in the section Can Training Status Protect Against COVID-19 Infection?. Paragraph five should read:

The contradictions displayed across the studies discussed above may be related to differences in the immune response to training status (more trained vs. less trained individuals). Some studies have reported reductions in the lymphocyte proliferative response (Papa et al., 1989) and suppressed neutrophil function (Lewicki et al., 1988; Baj et al., 1994), whereas other studies have shown no alteration in either lymphocyte or neutrophil status after a period of exercise (Tvede et al., 1991; Flynn et al., 1999; Ferrari et al., 2013), or even increases (Brunelli et al., 2014) when comparing different training statuses.

In addition, the citation has now been inserted in the section Can an Acute Exercise Session Increase the Risks for Covid-19 Infection?

Paragraph two

Several studies have investigated the effects of a single exercise session on immune function by measuring acute changes in various parameters (Flynn et al., 1999; Fahlman et al., 2000; Steensberg et al., 2001; Kakanis et al., 2010). However, few studies have utilized resistance exercise protocols (Nieman et al., 1995; Flynn et al., 1999) or home-based exercises, those likely to be performed during the current pandemic which most likely consist of adapted forms of resistance exercise.

\section{Paragraph three}

Nieman et al. (1995) had participants perform multiple sets of squat exercise to failure at $65 \%$ of one-maximum repetition (1-RM) and observed conflicting results with leukocytes counts 
increasing immediately post-exercise and remaining elevated up to $2 \mathrm{~h}$ after, whereas lymphocytes number increased postexercise but decreased below baseline levels $2 \mathrm{~h}$ post-exercise. Nonetheless, it is important to note that Nieman et al. (1995) utilized a sample of 10 resistance trained individuals with a mean age of $\sim 25$ years, however, COVID-19 is particularly dangerous to older individuals, which represents most of the COVID-19related deaths reported to date (Verity et al., 2020). Therefore, it is important to consider the potential immunosuppressive effects of resistance exercise for elderly participants. In this regard, Flynn et al. (1999) investigated the acute effects of a resistance exercise session performed at $80 \% 1-\mathrm{RM}$ on several immune function parameters in women aged 67 and 84 years and reported no suppression of immune function during the recovery period from the exercise bout. Finally, it is important to highlight that URTI incidences were not assessed in any of these studies.

\section{Paragraph five}

The different results across these studies may be due to the variability in the immune system responses to an acute exercise session. Although a number of studies have observed an immunosuppressive response after prolonged and intense exercise bouts (Steensberg et al., 2001; Kakanis et al., 2010), no

\section{REFERENCES}

Baj, Z., Kantorski, J., Majewska, E., Zeman, K., Pokoca, L., Fornalczy, E., et al. (1994). Immunological status of competitive cyclists before and after the training season. Int. J. Sports Med. 15, 319-324. doi: 10.1055/s-2007-10 21067

Brunelli, D. T., Rodrigues, A., Lopes, W. A., Gáspari, A. F., Bonganha, V., Montagner, P. C., et al. (2014). Monitoring of immunological parameters in adolescent basketball athletes during and after a sports season. J. Sports Sci. 32, 1050-1059. doi: 10.1080/02640414.2013.878806

Chen, P., Mao, L., Nassis, G. P., Harmer, P., Ainsworth, B. E., and Li, F. (2020). Coronavirus disease (COVID-19): The need to maintain regular physical activity while taking precautions. J. Sport Health. Sci. 9, 103-104. doi: 10.1016/j.jshs.2020.02.001

Fahlman, M. M., Boardley, D., Flynn, M. G., Braun, W. A., Lambert, C. P., and Bouillon, L. E. (2000). Effects of endurance training on selected parameters of immune function in elderly women. Gerontology 46, 97-104. doi: $10.1159 / 000022142$

Ferrari, H. G., Gobatto, C. A., and Manchado-Gobatto, F. B. (2013). Training load, immune system, upper respiratory symptoms and performance in welltrained cyclists throughout a competitive season. Biol. Sport 30, 289-294. doi: 10.5604/20831862.1077555

Flynn, M. G., Fahlman, M., Braun, W. A., Lambert, C. P., Bouillon, L. E., Brolinson, P. G., et al., (1999). Effects of resistance training on selected indexes of immune function in elderly women. J. Appl. Physiol. 86, 1905-1913. doi: 10.1152/jappl.1999.86.6.1905

Kakanis, M., Peake, J., Hooper, S., Gray, B., and Marshall-Gradisnik, S. (2010). The open window of susceptibility to infection after acute exercise in healthy young male elite athletes. J. Sci. Med. Sport 13, e84-e85. doi: 10.1016/j.jsams.2010.10.640

Kostka, T., Drygas, W., Jegier, A., and Praczko, K. (2008). Physical activity and upper respiratory tract infections. Int. J. Sports Med. 29, 158-162. doi: $10.1055 /$ s-2007-965806

Kostka, T., and Praczko, K. (2007). Interrelationship between physical activity, symptomatology of upper respiratory tract infections, and depression in elderly people. Gerontology 53, 187-193. doi: 10.1159/000100017 changes in immune function have also been observed (Flynn et al., 1999).

In the original article, there was an error. Incorrect references were cited.

A correction has been made to the section Can Training Status Protect Against Covid-19 Infection?, paragraph three:

On the other hand, other studies have shown no protective effects of exercise training programs on URTI incidences (Nieman et al., 1990; Kostka and Praczko, 2007; Kostka et al., 2008; Walsh et al., 2011). To illustrate, a study with obese sedentary women who completed 15 weeks of endurance training (walking at $60 \%$ heart rate reserve), five times a week, reported no differences in the number of URTI in comparison to the untrained control subjects (Nieman et al., 1990). However, the number of days with URTI symptoms was lower in the exercise group in comparison to the control group, which was confirmed by additional studies (Kostka and Praczko, 2007; Kostka et al., 2008; Walsh et al., 2011). An additional study did not find any relationship between perceived physical fitness levels and URTI incidences (Kostka et al., 2008).

The authors apologize for these errors and state that this does not change the scientific conclusions of the article in any way. The original article has been updated.
Lewicki, R., Tchorzewski, H., Majewska, E., Nowak, Z., and Baj, Z. (1988). Effect of maximal physical exercise on T-lymphocyte subpopulations and on interleukin 1 (IL 1) and interleukin 2 (IL 2) production in vitro. Int. J. Sports Med. 9, 114-117. doi: 10.1055/s-2007-1024990

Nieman, D. C., Henson, D. A., Sampson, C. S., Herring, J. L., Suttles, J., Conley, M., et al. (1995). The acute immune response to exhaustive resistance exercise. Int. J. Sports Med. 16, 322-328. doi: 10.1055/s-2007-973013

Nieman, D. C., Nehlsen-Cannarella, S. L., Markoff, P. A., Balk-Lamberton, A. J., Yang, H., Chritton, D. B. W., et al. (1990). The effects of moderate exercise training on natural killer cells and acute upper respiratory tract infections. Int. J. Sports Med. 11, 467-473. doi: 10.1055/s-2007-1024839

Papa, S., Vitale, M., Mazzotti, G., Neri, L. M., Monti, G., and Manzoli, F. A. (1989). Impaired lymphocyte stimulation induced by long-term training. Immunol. Lett. 22, 29-33. doi: 10.1016/0165-2478(89)90138-7

Steensberg, A., Toft, A. D., Bruunsgaard, H., Sandmand, M., Halkjær-Kristensen, J., and Pedersen, B. K. (2001). Strenuous exercise decreases the percentage of type $1 \mathrm{~T}$ cells in the circulation. J. Appl. Physiol. 91, 1708-1712. doi: 10.1152/jappl.2001.91.4.1708

Tvede, N., Steensberg, J., Baslund, B., Halkjær-Kristensen, J., and Pedersen, B. K. (1991). Cellular immunity in highly trained elite racing cyclists during periods of training with high and low intensity. Scand. J. Med. Sci. Sports 1, 163-166. doi: 10.1111/j.1600-0838.1991.tb00290.x

Verity, R., Okell, L. C., Dorigatti, I., Winskill, P., Whittaker, C., Imai, N., et al. (2020). Estimates of the severity of coronavirus disease 2019 : a model-based analysis. Lancet Infect. Dis. 3099, 1-9. doi: 10.1016/S1473-3099(20)30243-7

Walsh, N. P., Gleeson, M., Pyne, D. B., Nieman, D. C., Dhabhar, F. S., Shephard, R. J., et al. (2011). Position statement part two: maintaining immune health. Exerc. Immunol. Rev. 17, 64-103.

Copyright (C) 2020 Ferreira-Júnior, Freitas and Chaves. This is an open-access article distributed under the terms of the Creative Commons Attribution License (CC BY). The use, distribution or reproduction in other forums is permitted, provided the original author(s) and the copyright owner(s) are credited and that the original publication in this journal is cited, in accordance with accepted academic practice. No use, distribution or reproduction is permitted which does not comply with these terms. 